\title{
PENGARUH VOLATILITAS NILAI TUKAR TERHADAP KINERJA EKSPOR UTAMA PERTANIAN INDONESIA
}

\section{The Effect of Exchange Rate Volatility on Indonesian Main Agricultural Exports Performance}

\author{
Eka Dewi Satriana', ${ }^{1}$ Harianto ${ }^{2}$, Dominicus Savio Priyarsono ${ }^{3}$ \\ ${ }^{1}$ Program Studi Ilmu Ekonomi Pertanian, Sekolah Pascasarjana Institut Pertanian Bogor \\ 2Departemen Agribisnis, Fakultas Ekonomi dan Manajemen, Institut Pertanian Bogor \\ ${ }^{3}$ Departemen Ilmu Ekonomi, Fakultas Ekonomi dan Manajemen, Institut Pertanian Bogor \\ JI. Kamper, Kampus IPB Darmaga, Bogor, Jawa Barat, 16680, Indonesia \\ E-mail: satriana.eka@gmail.com
}

Naskah diterima: 29/10/2018; Naskah direvisi: 17/07/2019; Disetujui diterbitkan: 16/09/2019 Dipublikasikan online: 31/12/2019

\begin{abstract}
Abstrak
Nilai tukar merupakan salah satu aspek yang memengaruhi daya saing ekspor. Pada tahun 2013 hingga tahun 2015, volatilitas nilai tukar mengalami kenaikan, khususnya pada triwulan akhir tahun 2015 yaitu sebesar 16,90\%. Kondisi ekspor utama pertanian Indonesia pada tahun tersebut rata-rata mengalami penurunan. Penelitian ini bertujuan untuk menganalisis pengaruh volatilitas nilai tukar terhadap kinerja ekspor utama pertanian Indonesia ke negara mitra dagang utama dengan menggunakan gravity model. Ekspor utama pertanian yang dianalisis yaitu karet alam, kopi, udang, dan Crude Palm Oil (CPO). Model ARCH-GARCH digunakan untuk mengukur volatilitas nilai tukar. Hasil analisis menunjukkan bahwa volatilitas nilai tukar berpengaruh negatif terhadap ekspor karet alam, kopi, dan udang Indonesia. Artinya, semakin fluktuatif nilai tukar rupiah maka akan menurunkan ekspor karet alam, kopi, dan udang Indonesia ke negara mitra dagang utama. Pengaruh negatif tersebut juga menunjukkan adanya penghindaran risiko yang dilakukan oleh pelaku usaha. Beberapa rekomendasi hasil kajian yang dapat dilakukan Pemerintah Indonesia adalah menjaga stabilitas nilai tukar, kemudahan akses ke lembaga keuangan, penerapan lindung nilai (hedging), kontrak jangka panjang (longterm contracts), dan menjaga pertumbuhan produksi komoditas.
\end{abstract}

Kata Kunci: Volatilitas Nilai Tukar, Ekspor Utama Pertanian, Model ARCH-GARCH

\begin{abstract}
The exchange rate is one aspect that affects export competitiveness. From 2013 to 2015, exchange rate volatility increased, especially in the final quarter of 2015 , which was $16.90 \%$. Indonesia's main agricultural export conditions in the year on average experienced a decline. This paper analyzes the effect of exchange rate volatility on the performance of Indonesia's main agricultural exports to major trading partner countries using the gravity model. The main agricultural exports analyzed were natural rubber, coffee, shrimp, and Crude Palm Oil (CPO). The ARCH-GARCH model is used to measure exchange rate volatility. The analysis shows that exchange rate volatility harms on Indonesia's exports of natural rubber, coffee, and shrimp. This means, the more the rupiah exchange rate fluctuates will reduce Indonesia's natural rubber, coffee and shrimp exports to the main trading partner countries. The negative influence also indicates the existence of risk aversion by business actors. Some recommendations for the Government of Indonesia based on the study findings are maintaining exchange rate stability, easy access to financial institutions, implementing hedging, long-term contracts, and maintaining commodity production growth.
\end{abstract}

Keywords: Exchange Rate Volatility, Main Agricultural Exports, ARCH-GARCH Model JEL Classification: F14, F31, F41, Q17 


\section{PENDAHULUAN}

Pengaruh volatilitas nilai tukar terhadap perdagangan merupakan salah satu isu yang menjadi perhatian dalam ekonomi internasional (Broll \& Eckwert, 1999; Oztruk, 2006). Volatilitas nilai tukar dapat diartikan sebagai seberapa banyak dan cepatnya nilai tukar mata uang suatu negara terhadap negara lain berubah dari waktu ke waktu. Adanya volatilitas nilai tukar tersebut, menjadikannya sebagai sumber dari ketidakpastian (risiko) nilai tukar yang salah satunya dapat berimplikasi terhadap volume perdagangan dan pada akhirnya berakibat pada neraca perdagangan (Oztruk, 2006). Hal ini mengingat bahwa nilai mata uang ikut menentukan seberapa besar harga yang akan dibayarkan oleh importir dan diterima oleh eksportir. Mekanisme ini pada akhirnya akan menentukan seberapa besar profit yang akan diterima dari kegiatan ekspor dan impor tersebut.

Sejak tahun 1997, Indonesia mengubah sistem nilai tukarnya. Perubahan sistem nilai tukar yang dilakukan adalah dari sistem nilai tukar mengambang terkendali (managed floating exchange rate) menjadi sistem nilai tukar mengambang bebas (freely floating exchange rate). Sistem nilai tukar mengambang bebas (freely floating exchange rate) mengakibatkan Indonesia tidak dapat terlepas dari fenomena volatilitas nilai tukar yang dapat mengganggu aktivitas ekonomi, khususnya kegiatan perdagangan internasional seperti ekspor. Salah satu andalan ekspor Indonesia adalah ekspor berbasis pertanian. Ekspor pertanian Indonesia merupakan salah satu motor penggerak pertumbuhan ekonomi, penyerap tenaga kerja, dan penyumbang devisa negara. Adapun komoditas ekspor unggulan pertanian Indonesia yakni karet alam, kopi, udang, dan Crude Palm Oil (CPO). Keempat komoditas ekspor unggulan pertanian tersebut juga termasuk sebagai 10 komoditas ekspor utama Indonesia (Kemendag, 2017).

Krisis global pada tahun 2008 mengakibatkan nilai tukar rupiah sangat berfluktuasi, terutama pada kuartal akhir tahun tersebut. Fluktuasi tersebut disertai dengan meningkatnya volatilitas nilai tukar. Volatilitas nilai tukar meningkat dari $1,44 \%$ pada tahun 2007 menjadi 4,67\% pada tahun 2008 (Bank Indonesia, 2008). Gejolak eksternal tersebut menyebabkan penurunan ekspor komoditas karet 
alam, kopi dan udang Indonesia, terutama pada kuartal akhir. Pada kuartal akhir 2008, ekspor komoditas karet alam, kopi dan udang Indonesia mengalami penurunan masing-masing sebesar $45,50 \%, 37,52 \%$, dan $34,50 \%$. Penurunan tersebut terus berlanjut pada tahun berikutnya. Sedangkan ekspor CPO Indonesia pada kuartal akhir 2008 mengalami peningkatan ekspor sebesar 27,04\%. Namun pada kuartal selanjutnya, ekspor CPO Indonesia mengalami penurunan sebesar $38,50 \%$.

Nilai tukar rupiah kembali mengalami tekanan depresiasi yang relatif tinggi dan volatilitas nilai tukar yang meningkat pada tahun 2013 hingga 2015. Terutama volatilitas nilai tukar pada kuartal akhir tahun 2015 yakni sebesar 16,90\% (Bank Indonesia, 2015). Kondisi ekspor utama pertanian selama tiga tahun tersebut mengalami rata-rata penurunan, terutama pada ekspor komoditas karet alam dan kopi Indonesia.

Sektor pertanian merupakan sektor yang paling rentan terkena pengaruh volatilitas nilai tukar dibandingkan sektor lainnya (Klein, 1990; Orden, 2002; Cho et al. 2002;
Wang \& Barrett, 2007; Kandilov, 2008; Kafle dan Kennedy, 2011).

Beberapa studi empiris telah menganalisis pengaruh volatilitas nilai tukar terhadap perdagangan pertanian, khususnya terkait ekspor pertanian. Namun tidak ada hubungan yang jelas antara volatilitas nilai tukar dan ekspor pertanian. Seperti Klein (1990) dan Almawarni et al. (2007) menunjukkan bahwa volatilitas nilai tukar berpengaruh positif terhadap ekspor pertanian. Sedangkan Pick (1990), Cho et al. (2002), Wang \& Barrett (2007), Kandilov (2008), Kafle \& Kennedy (2011), dan Sheldon et al (2013) menunjukkan pengaruh negatif terhadap ekspor pertanian. Serta Langley et al. (2000) dalam studinya mejelaskan bahwa volatilitas nilai tukar tidak signifikan memengaruhi ekspor pertanian secara agregat, namun berpengaruh negatif dan signifikan terhadap ekspor unggas.

Penelitian mengenai pengaruh volatilitas nilai tukar terhadap ekspor pertanian Indonesia telah dikaji oleh Zainal (2008). Penelitian tersebut menganalisis pengaruh volatilitas nilai tukar terhadap beberapa komoditi ekspor Indonesia, termasuk komoditi ekspor pertanian Indonesia secara 
agregat dengan data time series dari Juli 1997 sampai Agustus 2002. Hasil penelitian menunjukkan bahwa volatilitas nilai tukar cenderung menurun selama periode pengamatan. Sedangkan pengaruh volatilitas nilai tukar terhadap ekspor agregat pertanian Indonesia menunjukkan bahwa volatilitas nilai tukar tidak berpengaruh signifikan.

Pengaruh volatilitas nilai tukar bisa saja disebabkan pengaruh yang berbeda di tingkat komoditas, sehingga pada ekspor pertanian yang dihasilkan merupakan kumulatif dari komoditaskomoditas ekspor pertanian. Berdasarkan hal itu, penelitian ini berkontribusi untuk melengkapi penelitian sebelumnya dengan berfokus pada ekspor utama pertanian Indonesia. Adapun ekspor utama pertanian Indonesia tersebut yakni karet alam, kopi, udang, dan CPO.

Nilai tukar merupakan salah satu aspek yang memengaruhi daya saing komoditas ekspor pertanian (Tweeten, 1992). Jika nilai tukar negara eksportir mengalami depresiasi, maka negara importir memandang harga komoditas di negara eksportir relatif murah, maka pada akhirnya permintaan negara eksportir akan meningkat. Sehingga, adanya ketidakpastian (risiko) nilai tukar yang disebabkan oleh volatilitas nilai tukar diduga akan memengaruhi ekspor utama pertanian Indonesia. Oleh karena itu, penelitian ini bertujuan untuk menganalisis pengaruh volatilitas nilai tukar terhadap kinerja ekspor utama pertanian Indonesia ke negaranegara mitra dagang utamanya.

\section{METODE}

\section{Gravity Model}

Analisis regresi data panel dengan gravity model digunakan untuk menganalisis pengaruh volatilitas nilai tukar terhadap ekspor utama pertanian Indonesia. Gravity model telah digunakan dalam banyak penelitian ekonomi terkait arus perdagangan internasional dengan memperkuat dasar teorinya. Penggunaan gravity model dalam beberapa studi empiris arus perdagangan internasional digunakan karena efisiensinya mencakup berbagai variabel seperti pengaruh volatilitas nilai tukar, perbatasan negara, bahasa, ketersediaan infrastruktur, kesamaan sejarah, dan lainnya (Wang \& Barret, 2007; Dell'Ariccia, 1999; Kafle \& Kennedy, 2011).

Gravity model dalam bentuk dasarnya menyatakan bahwa ekspor 
dari negara eksportir ke negara importir $E X P_{j t}$ berbanding lurus dengan massa ekonomi kedua negara yang biasanya ditunjukkan oleh Produk Domestik Bruto (PDB) atau Gross Domestic Product (GDP) negara eksportir dan importir dan berbanding terbalik dengan jarak $E D I S T_{j t}$ antara kedua negara. Persamaan tersebut kemudian dimasukkan faktor lain atau variabel lain yang dapat membuat resistensi perdagangan, seperti volatilitas nilai tukar $V N T_{j t}$ (Kandilov, 2008). Sehingga bentuk gravity model mengikuti persamaan yang dibentuk oleh Kandilov (2008) menjadi sebagai berikut:

$E X P_{j t}=\frac{\alpha_{0^{*}}\left(G D P I N A_{t}^{\alpha_{1}}\right) \cdot\left(G D P M_{j t}{ }^{\alpha_{2}}\right) \cdot \varepsilon_{j t}}{E D I S T_{j t}^{\alpha_{I}} \cdot \exp \left(\alpha_{4} V N T_{j t}\right)}$

dimana $\varepsilon_{\text {jt }}$ adalah error term, dan $\alpha$ adalah parameter yang akan diestimasi. Kemudian persamaan 1 akan di-log-linear-kan menjadi:

$\ln E X P_{j t}=\ln \alpha_{0}+\alpha_{1} \ln G D P I N A_{t}+\alpha_{2} \ln G D P M_{j t}+\alpha_{3} \ln E D I S T_{j t}+\alpha_{4} V N T_{j t}+\varepsilon_{j t}$

dimana $\alpha_{0}$ adalah intersep, $\alpha_{1} \ldots \alpha_{4}$ merupakan parameter masing-masing variabel yang akan diuji secara statistik dan ekonometrik, $\varepsilon_{j t}$ merupakan error term. $E X P_{j t}$ merupakan volume ekspor utama pertanian riil Indonesia ke negara mitra dagang utamanya (importir) $j$ pada waktu $t$ yang diamati (juta USD). Variabel volume ekspor utama pertanian riil $\left(E X P_{j t}\right)$ diukur dengan menggunakan Indeks Harga Perdagangan Besar (IHPB) Indonesia sebagai deflatornya. GDPINA merupakan GDP riil Indonesia (juta USD). $G D P M_{j t}$ merupakan GDP riil negara-negara mitra dagang utama (juta USD). ${ }^{E D I S T} T_{j t}$ merupakan jarak ekonomi Indonesia ke negara mitra dagang utamanya (importir) j pada waktu $t$ yang diamati, dan variabel $V N T_{j t}$ merupakan volatilitas nilai tukar rupiah riil terhadap USD. Dalam penelitian ini, volatilitas nilai tukar yang diestimasi menggunakan nilai tukar nominal.

\section{Pengukuran Volatilitas Nilai Tukar}

Pada umumnya, ukuran volatilitas nilai tukar menggunakan nilai standar deviasi bersyarat (conditional standard deviation) dari nilai tukar tahunan, kuartalan, atau bulanan seperti pada penelitian Rose (2000), Cho et al. (2002), Kandilov (2008), Kafle \& 
Kennedy (2011), Mukhtar \& Malik (2010), Chit et al. (2010), Asteriou et al. (2016), Senadza \& Diaba (2017), dan Aftab et al. (2017). Penelitian ini menggunakan model ARCH-GARCH untuk mengestimasi besaran volatilitas nilai tukar rupiah riil terhadap USD yang telah diubah kedalam bentuk logaritma natural.

Model ARCH digunakan untuk mengestimasi data yang memiliki volatilitas tinggi. Sehingga ragam residual akan tergantung pada ragam residual periode yang lalu. Model ARCH pertama kali diperkenalkan oleh Engle (1982). Persamaan model ARCH adalah sebagai berikut:

$\sigma^{2}{ }_{t}=\alpha_{0}+\alpha_{1} e^{2}{ }_{t-1}$

$h_{t}=K+\delta_{1} h_{t-1}+\delta_{2} h_{t-2}+\cdots+\delta_{r} h_{t-r}+\alpha_{1} \varepsilon_{t-1}^{2}+\alpha_{2} \varepsilon_{t-2}^{2}+\cdots+\alpha_{m} \varepsilon_{t-m}^{2}$

dimana:

$h_{t} \quad$ : Variabel logaritma natural nilai tukar rupiah riil terhadap USD pada waktu t/varians pada waktu ke-t

$K \quad$ : Varian yang konstan

$\varepsilon^{2}{ }_{t-m}$ : Suku ARCH/ volatilitas pada periode sebelumnya $\alpha_{1}, \alpha_{2}, \ldots, \alpha_{m}$ : Koefisien ordo $m$ yang diestimasikan
Persamaan (3) menunjukkan ragam residual $\left(\sigma_{t}^{2}\right)$ yang memiliki unsur konstanta $\left(\alpha_{0}\right)$ dan kuadrat residual periode yang lalu $\left(e^{2}{ }_{t-1}\right)$. Model dari residual $e_{t}$ adalah heteroskedasitas yang bersyarat pada residual $e^{2}{ }_{t-1}$. Persamaan (3) adalah model ARCH (1) karena ragam dari residual et hanya dari fluktuasi residual kuadrat satu periode sebelumnya. Model ARCH kemudian digenarilisasi menjadi model GARCH oleh Bollerslev (1986). Model $\mathrm{GARCH}(r, m)$ mengasumsikan bahwa varian data fluktuasi dipengaruhi sejumlah $\mathrm{m}$ data fluktuasi sebelumnya dan sejumlah $r$ data volatilitas sebelumnya. Bentuk umum model $\operatorname{GARCH}(r, m)$ :

$$
\begin{aligned}
\delta_{1}, \delta_{2}, \ldots, \delta_{m} & : \text { Koefisien ordo } r \text { yang } \\
& \text { diestimasikan } \\
h_{t-r} \quad: & \text { Suku GARCH/ varian } \\
& \text { periode sebelumnya }
\end{aligned}
$$

Ada beberapa tahapan estimasi untuk dapat membangun model $\mathrm{ARCH}$ GARCH. Tahapan tersebut yakni (1) uji stasioneritas terhadap data yang akan dilakukan analisis, (2) identifikasi model Box-Jenkins, (3) uji efek ARCH dari model Box-Jenkins yang terpilih. Uji ini 
akan menentukan apakah model yang dipilih dapat dianalisis lebih lanjut menggunakan model ARCH-GARCH, (4) estimasi model ARCH-GARCH dengan memilih model terbaik, dan (5) evaluasi model yang terpilih menggunakan uji normalitas dan melakukan uji ARCH-LM untuk mengetahui model ARCH/GARCH yang dipilih sudah terbebas dari efek $\mathrm{ARCH}$.

Seluruh data yang digunakan merupakan data sekunder berupa data panel, data yang menggabungkan data time series dan cross section. Data time series dimulai dari kuartal pertama 2000 sampai dengan kuartal ke empat 2015. Data cross section yang dianalisis yaitu lima negara mitra dagang utama ekspor karet alam, kopi, udang dan CPO Indonesia. Adapun negara-negara mitra dagang utama ekspor karet alam Indonesia yaitu Amerika Serikat, Jepang, Tiongkok, India, dan Korea Selatan. Negaranegara mitra dagang utama ekspor kopi Indonesia yaitu Amerika Serikat, Jepang, Jerman, Malaysia, dan Italia. Negara-negara mitra dagang utama ekspor udang Indonesia yaitu Amerika Serikat, Jepang, Tiongkok, Vietnam, dan Kanada. Sedangkan negaranegara mitra dagang utama ekspor CPO Indonesia yaitu India, Belanda, Italia, Singapura, dan Spanyol. Kode Harmonized System (HS) yang digunakan untuk masing-masing komoditas ekspor pertanian yang diteliti yaitu 4001101000-4001229000 (karet alam), 090111300-090111900 (kopi), 0306160000-0306179000 (udang), dan 1511100000 (CPO).

\section{Tabel 1. Jenis dan Sumber Data}

\begin{tabular}{lll}
\hline \multicolumn{1}{c}{ Data } & \multicolumn{1}{c}{ Sumber Data } & \multicolumn{1}{c}{ Nama Publikasi } \\
\hline Ekspor & Badan Pusat Statistik & Statistik Perdagangan Luar \\
& & Negeri: Ekspor \\
GDP importir & International Financial Statistics & GDP and Components (online: \\
& $($ IFS) & $\underline{\text { www.data.imf.org/en/data) }}$ \\
GDP Indonesia & Badan Pusat Statistik & Indikator Ekonomi \\
Nilai Tukar & Bank Indonesia & Kurs Referensi JISDOR (online: \\
Jarak & CPII & www.bi.go.id) \\
\hline
\end{tabular}


HASIL DAN PEMBAHASAN

Gambaran Umum Komoditas Ekspor Utama Pertanian Indonesia

Indonesia merupakan produsen karet alam terbesar kedua di dunia setelah Thailand. Sebagian besar produksi karet alam Indonesia diekspor ke manca negara dan sisanya dipasarkan di dalam negeri. Produksi karet alam Indonesia dari periode 20002015 menunjukkan tren yang relatif meningkat (Gambar 1) dengan rata-rata pertumbuhan sebesar $4,58 \%$ per tahun. Produksi tertinggi terjadi pada tahun 2013 yakni sebesar 3237,43 ribu ton yang kemudian mengalami penurunan pada tahun selanjutnya. Penurunan produksi terbesar terjadi di tahun 2009 sebesar $12,41 \%$. Penurunan tersebut merupakan efek dari krisis ekonomi pada akhir tahun 2008 dan berlanjut pada tahun 2009. Pada tahun tersebut, perekonomian negara utama importir karet alam Indonesia mengalami kondisi yang tidak stabil sehingga permintaan karet alam Indonesia mengalami penurunan (Syafendi, 2014). Berdasarkan data Ditjen Perkebunan, pada tahun 2009 juga terjadi penurunan produktivitas karet alam Indonesia yang cukup besar yakni sebesar $9,36 \%$.
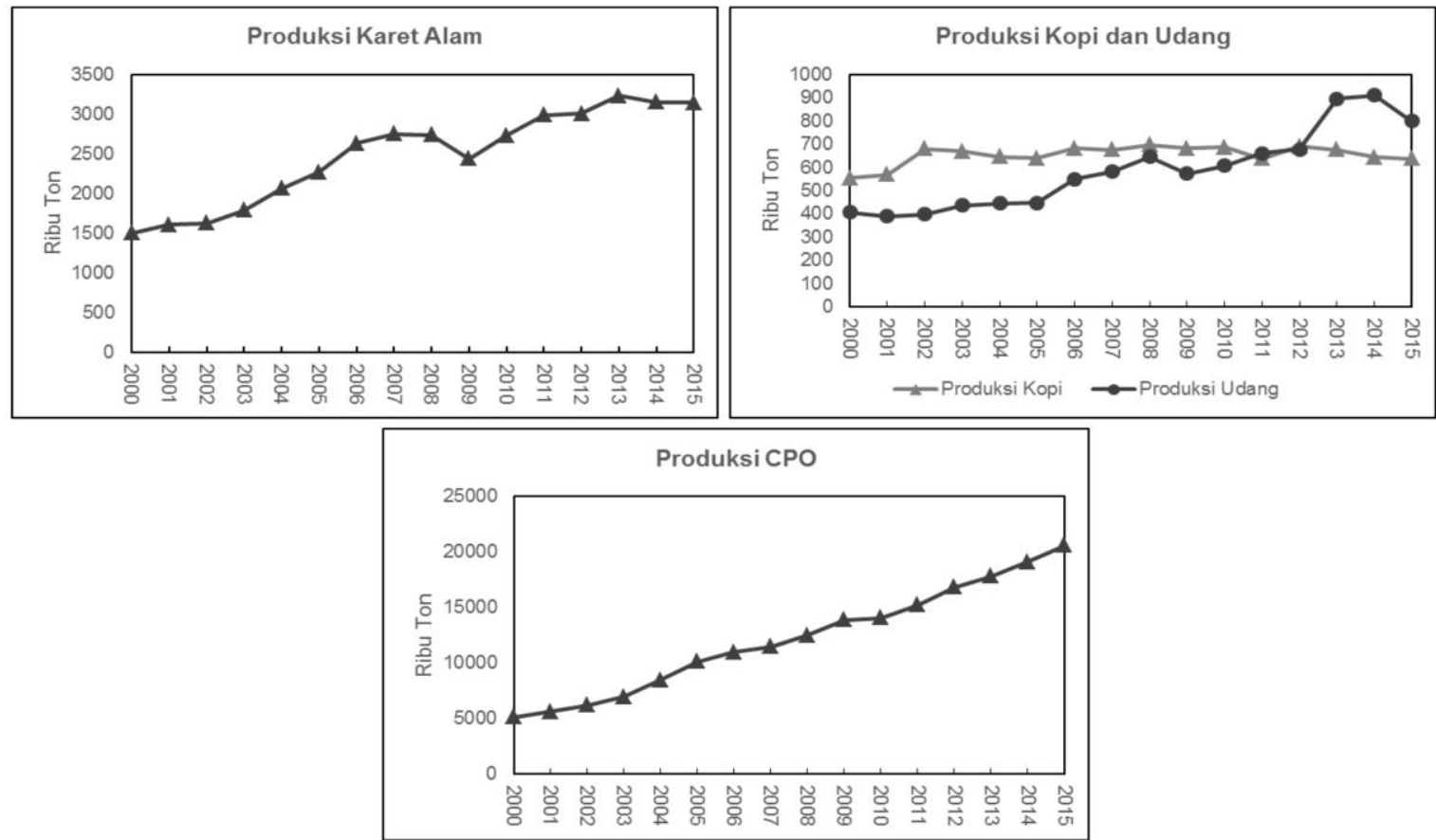

Gambar 1. Perkembangan Produksi Komoditas Ekspor Utama Pertanian Indonesia, Tahun 2000-2015

Sumber: Direktorat Jenderal Perkebunan (2016a, 2016b, 2016c) dan Kementrian Kelautan dan Perikanan $(2013,2015)$ 
Kopi Indonesia juga termasuk produsen terbesar kopi di dunia. Produksi kopi Indonesia dari tahun 2000 hingga tahun 2015 cenderung dalam kondisi stagnan (Gambar 1). Sebanyak 70\% produksi kopi Indonesia diekspor ke mancanegara dan hanya sekitar 30\% yang digunakan untuk konsumsi domestik. Kondisi ini menggambarkan bahwa kopi Indonesia sangat bergantung pada pasar ekspor. Sedangkan produksi kopi Indonesia didominasi oleh perkebunan rakyat yang berdampak signifikan apabila situasi pasar dalam negeri dan internasional berada dalam kondisi yang tidak stabil, sehingga memengaruhi keputusan petani rakyat (Muzendi, 2014; Shabrina, 2016). Terlihat pada saat krisis tahun 2009, produksi kopi Indonesia mengalami penurunan sebesar $2,24 \%$. Produksi kopi kembali mengalami penurunan dari tahun 2013 hingga tahun 2015 dengan rata-rata penurunan sebesar $2,64 \%$ per tahun. Berdasarkan data Ditjen perkebunan, terjadi penurunan luas areal kopi Indonesia pada periode 2000-2015 yakni dari 1269,80 ribu hektar pada tahun 2000 menjadi 1229,80 ribu hektar di tahun 2015. Penurunan terbesar terjadi pada rentang tahun 2008-2010 dengan ratarata penurunan sebesar $2,32 \%$ per tahun. Sedangkan produktivitas kopi Indonesia masih rendah jika dibanding dengan negara eksportir kopi lainnya seperti Vietnam. Padahal luas areal kopi Indonesia dua kali lebih besar dari luas areal kopi Vietnam. Hal ini disebabkan oleh keterbatasan modal petani rakyat, tanaman kopi yang sudah berumur tua, dan teknologi yang masih rendah (Firmansyah, 2016).

Udang merupakan salah satu komoditas perikanan Indonesia yang bernilai tinggi dan termasuk sebagai salah satu eksportir terbesar di dunia. Produksi udang Indonesia periode 2000-2015 menunjukkan tren yang relatif meningkat (Gambar 1). Produksi terbesar terjadi pada tahun 2014 yakni sebesar 912,50 ribu ton dan terjadi penurunan di tahun berikutnya. Sedangkan penurunan yang cukup tajam terjadi pada tahun 2009 yaitu sebesar 12,45\%. Produksi udang Indonesia dihasilkan dari kegiatan budidaya tambak (70\%) dan penangkapan di perairan laut dan umum $(30 \%)$. Produksi udang hasil penangkapan relatif stabil dibandingkan dengan udang yang berasal dari hasil budidaya (Ashari, 2016). Udang putih 
mendominasi perikanan tangkap.

Sedangkan udang vaname dan udang windu pada perikanan budidaya. Sebagian besar produksi udang Indonesia diekspor ke berbagai negara. Udang vaname merupakan varietas udang Indonesia yang banyak diekspor dengan kontribusi volume ekspor mencapai 85\%.

CPO Indonesia merupakan produsen terbesar di dunia. Produksi CPO Indonesia dari tahun ke tahun terus mengalami peningkatan (Gambar 1). Rata-rata peningkatan produksi CPO Indonesia dari tahun 2000 hingga tahun 2015 sebesar 12,16 \% per tahun. Kondisi luas areal kelapa sawit Indonesia juga mengalami peningkatan dengan rata-rata peningkatan sebesar $6,39 \%$ per tahun. Menurut status pengusahaannya pada tahun 2015, sebagian besar perkebunan kelapa sawit Indonesia didominasi oleh perkebunan besar swasta yakni sebesar $52 \%$, sementara perkebunan rakyat mengusahakan $41 \%$, dan sisanya $7 \%$ diusahakan oleh perkebunan besar negara.

\section{Volatilitas Nilai Tukar}

Sebelum melakukan estimasi pengaruh volatilitas nilai tukar terhadap ekspor utama pertanian Indonesia, dilakukan terlebih dahulu pengukuran volatilitas nilai tukar. Data nilai tukar rupiah dalam bentuk logaritma natural yang akan dilakukan pengukuran nilai volatilitasnya terlebih dahulu diuji kestasioneran datanya. Uji ini dilakukan untuk mengetahui apakah data yang akan dianalisis mengandung akar unit. Uji akar unit dilakukan dengan menggunakan uji Augmented Dickey Fuller (ADF). Hasil uji Augmented Dickey Fuller yang tertera pada Tabel 2 menunjukkan bahwa variabel nilai tukar tidak stasioner pada level. Hal ini dapat dilihat dari nilai ADF statistik lebih besar daripada nilai kritis Mackinnon. Data yang tidak stasioner pada level kemudian dilakukan uji stasioner pada first difference, hasil yang diperoleh menunjukkan bahwa data stasioner pada kondisi ini. Hal ini ditunjukkan pada nilai ADF statistic yang lebih kecil dibandingkan nilai kritis Mackinnon pada taraf nyata $1 \%$.

Tabel 2. Hasil Uji Augmented Dickey Fuller

\begin{tabular}{cccc}
\hline \multirow{2}{*}{ Variabel } & \multicolumn{2}{c}{ ADF Statistic } & Nilai kritis Mackinnon \\
\cline { 2 - 4 } & Level & First Difference & \\
\hline Nilai Tukar & $-1,793835$ & $-5,339644$ & $-3,542097$ \\
\hline
\end{tabular}


Setelah uji stasioneritas pada data nilai tukar rupiah, maka model BoxJenkins dapat dibangun. Jika data stasioner pada first difference maka pendugaan model Box-Jenkins menggunakan model ARIMA. Model ARIMA $(2,1,2)$ merupakan model ARIMA yang terpilih setelah melakukan beberapa simulasi model ARIMA. Kemudian dilakukan uji efek $\mathrm{ARCH}$. Pengujian ini dilakukan untuk mengetahui ada tidaknya masalah heteroskedasitas. Uji efek $\mathrm{ARCH}$ dilakukan dengan menggunakan uji
$\mathrm{ARCH}-\mathrm{LM}$. Ada tidaknya efek $\mathrm{ARCH}$ dalam model ARIMA terpilih ditunjukkan dari nilai probabilitas uji ARCH-LM. Nilai probabilitas variabel nilai tukar rupiah kurang dari taraf nyata 5\% (Tabel 3 ), sehingga disimpulkan terdapat masalah heteroskedasitas pada variabel nilai tukar rupiah. Efek $\mathrm{ARCH}$ yang ditemukan tersebut mengindikasikan bahwa volatilitas yang dihitung bervariasi antar waktu (time varying). Adanya masalah tersebut dapat dilanjutkan dengan mengaplikasikan model ARCH-GARCH.

\section{Tabel 3. Hasil Uji ARCH-LM}

\begin{tabular}{cccc}
\hline Variabel & Model ARIMA Terbaik & F-Statistik & Probabilitas \\
\hline Nilai Tukar Rupiah & $(2,1,2)$ & 4,729862 & 0,0337 \\
\hline
\end{tabular}

Pada tahap selanjutnya dilakukan estimasi terhadap beberapa model ragam tentatif dan kemudian dipilih model terbaik. Model ARCH-GARCH yang terpilih adalah model $\mathrm{ARCH}(1)$. Setelah didapatkan model $\mathrm{ARCH}$ GARCH terbaik, selanjutnya dilakukan evaluasi terhadap model tersebut. Evaluasi model dilakukan melalui uji normalitas dengan memperhatikan nilai statistik Jarque-Bera. Hasil yang diperoleh menunjukkan bahwa nilai Jarque-Bera signifikan secara statistik dengan nilai probabilitasnya kurang dari taraf nyata $5 \%$ (Tabel 4). Hal ini berarti bahwa error model terdistribusi tidak normal. Sehingga cara yang dapat dilakukan untuk mengatasi ketidaknormalan error dengan menggunakan Heteroscedasticity Consistent Covariance BoolerslevWooldrige. 
Tabel 4. Hasil Uji Normalitas pada Model ARCH(1)

\begin{tabular}{ccc}
\hline Variabel & Jarque-Bera & Probabilitas \\
\hline Nilai Tukar Rupiah & 6,54 & 0,04 \\
\hline
\end{tabular}

Selanjutnya yang dilakukan untuk Hasil yang diperoleh dari uji ARCH-LM mengevaluasi ARCH-GARCH terpilih, menunjukkan bahwa model $\mathrm{ARCH}(1)$ yakni dengan melakukan uji ARCH-LM. sudah terbebas dari efek ARCH.

Tabel 5. Estimasi Parameter Model ARCH(1)

\begin{tabular}{ccccc}
\hline \multirow{2}{*}{ ARCH } & \multicolumn{5}{c}{ OPG } \\
\cline { 2 - 5 } & Coef. & Std. Err. & $\mathbf{Z}$ & $\mathbf{P}>|\mathbf{Z}|$ \\
\hline$\alpha_{0}$ & 0,000508 & 0,000151 & 3,360704 & 0,0008 \\
$\alpha_{1}$ & 1,488839 & 0,557721 & 2,669503 & 0,0076 \\
\hline
\end{tabular}

Keterangan: OPG Singkatan dari Outer Product of the Gradient

Tabel 5 menunjukkan hasil estimasi tukar rupiah. Ukuran volatilitas yang parameter $\mathrm{ARCH}(1)$, nilai $\alpha_{0}$ dan $\alpha_{1}$ digunakan adalah nilai standar deviasi signifikan pada taraf nyata $1 \%$, bersyarat (conditional standard sehingga dapat digunakan untuk deviation) yang merupakan akar dari melakukan pengukuran volatilitas nilai ragam model $\mathrm{ARCH}(1)$.

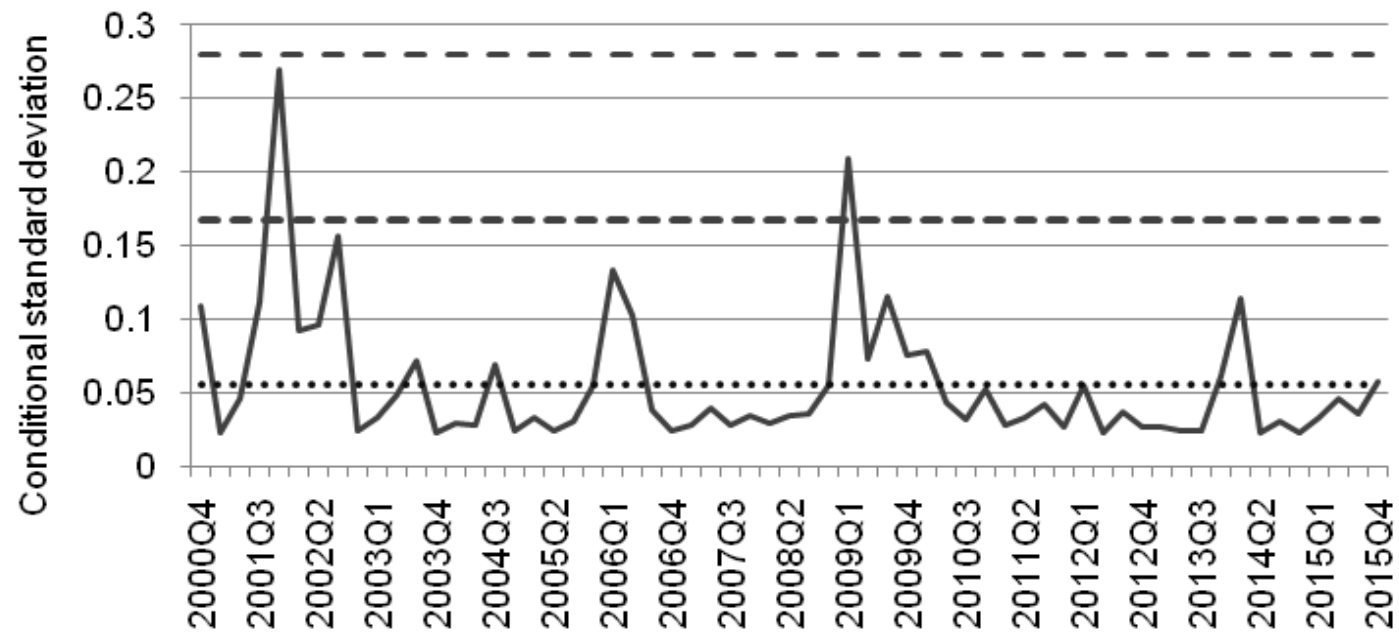

Periode

— Volatilitas Nilai Tukar Mean -----(+)2Stdev - - - (+)4Stdev

\section{Gambar 2. Volatilitas Nilai Tukar Rupiah terhadap USD}

Sumber: Bank Indonesia (2017), diolah 
Selama selang tahun 2000 hingga 2015, volatilitas nilai tukar rupiah tertinggi terjadi pada tahun 2001 yakni hampir mendekati empat standar deviasi. Hal tersebut disebabkan oleh kondisi eksternal dan internal Indonesia. Kondisi eksternal Indonesia pada tahun tersebut mengalami keadaan tidak stabil yang disebabkan oleh perekonomian dunia yang mengalami resesi. Adanya resesi berawal dari melemahnya kepercayaan internasional terhadap menurunnya investasi dibidang teknologi informasi. Penggunaan teknologi informasi telah meluas ke berbagai negara, sehingga dengan adanya penurunan investasi teknologi informasi tersebut memberikan pengaruh yang besar bagi banyak negara, terutama negaranegara maju. Selain itu, perlambatan ekonomi dunia diperburuk dengan adanya tragedi WTC yang terjadi pada 11 September 2001 (Bank Indonesia, 2001). PDB dunia pada tahun ini sebesar $2,4 \%$, lebih rendah dari tahun 1998 yakni sebesar 2,8\% (World Bank, 2018). Di sektor pertanian, harga bahan mentah pertanian (agricultural raw materials) secara keseluruhan menurun sebesar 7\%. Penurunan paling tajam terjadi pada bahan minuman yakni lebih besar dari pada tahun 1997, khususnya terjadi pada komoditas kopi. Sementara itu, ratarata harga pangan naik sebesar 3\% (FAO, 2002).

Tragedi 11 September membuat suhu politik internasional meningkat dan berimbas ke Indonesia berupa reaksi-reaksi yang menimbulkan rasa risk averse (penghindaran risiko) bagi investor asing (Bank Indonesia, 2001). Ditengah ketidakstabilan perekonomian dunia, kondisi internal Indonesia juga mengalami kondisi yang tidak stabil, karena adanya pengalihan pimpinan negara melalui sidang istimewa MPR RI. Saat itu, presiden Abdurahman Wahid digantikan wakilnya Megawati Soekarno Putri. Kondisi ini sangat berpengaruh terhadap kondisi makro ekonomi Indonesia, salah satunya dapat dilihat melalui tingginya volatilitas nilai tukar pada tahun tersebut.

Akhir tahun 2008, volatilitas nilai tukar rupiah kembali meningkat tajam yakni diatas dua standar deviasi (Gambar 2). Terjadi krisis ekonomi global yang dikenal sebagai krisis subprime mortgage di Amerika Serikat, yaitu ketika kredit perumahan diberikan kepada para debitur yang memiliki portofolio kredit buruk. Efek domino 
krisis ini menyebar ke Eropa dan kawasan ekonomi lainnya, termasuk Indonesia. Pertumbuhan PDB dunia pada tahun ini sebesar $1,80 \%$ dan mengalami penurunan di tahun berikutnya dengan pertumbuhan PDB dunia sebesar -1,74 (World Bank, 2018). Selain itu, harga pangan mengalami kenaikan sehingga terjadi krisis pangan. Kenaikan tersebut dimulai sejak tahun 2007 (Hardjanto, 2014). Harga pangan yang sangat tinggi memicu kerusuhan di banyak negara pada tahun 2008. Setidaknya 40 negara memberlakukan tindakan darurat seperti kontrol bahan pangan dan pembatasan ekspor (FAO, 2008). Kenaikan tajam harga pangan global dan masalah ketersediaan pangan mengancam ketahanan pangan global. Bagi Indonesia, pengaruh krisis pangan tersebut menyebabkan inflasi IHK meningkat tajam mencapai 11,06\% (Badan Pusat Statistik, 2008). Peningkatan inflasi dipengaruhi oleh komoditas pangan impor, salah satunya kedelai. Harga kedelai pada tahun 2008 mengalami peningkatan yang cukup tajam (Hardjanto, 2014). Meningkatnya volatilitas nilai tukar rupiah cenderung diakibatkan oleh krisis ekonomi global atau krisis subprime mortgage. Hal ini dikarenakan jatuhnya berbagai lembaga keuangan besar di Amerika Serikat dan proses deleveraging di pasar keuangan global. Sehingga meningkatkan risiko secara global yang memicu pelepasan investasi portofolio asing di pasar keuangan Indonesia. Di sisi lain, neraca transaksi berjalan mulai tertekan akibat jatuhnya harga komoditas dan merosotnya kegiatan ekonomi mitra dagang Indonesia (Bank Indonesia, 2008).

Mulai kuartal akhir tahun 2013 hingga tahun selanjutnya menunjukkan kondisi volitalitas nilai tukar rupiah mengalami peningkatan yang relatif tajam. Hal ini disebabkan oleh kondisi eksternal dan internal Indonesia. Kondisi eksternal, volatilitas nilai tukar yang terjadi tidak terlepas dari pemulihan ekonomi global yang berjalan lambat dan adanya penurunan harga-harga komoditas global, termasuk harga komoditas karet alam dan CPO. Suhu geopolitik Ukraina, Rusia, dan negara di Timur Tengah memicu peningkatan risiko di negara berkembang, sehingga mendorong aliran keluar non residen dalam beberapa periode (Bank Indonesia, 2014). Selain itu, adanya rencana 
normalisasi The Fed seiring perbaikan ekonomi Amerika Serikat yang memicu dollar terus menguat.

Perkembangan dalam negeri yang kurang menguntungkan memicu terjadinya volatilitas nilai tukar rupiah yang tajam. Tekanan nilai tukar dipicu oleh defisit transaksi berjalan yang terus berlanjut dari tahun sebelumnya serta hasil pemilu legislatif yang kurang kondusif diakibatkan oleh tidak adanya partai politik yang menguasai suara secara dominan dan terjadinya proses pembentukan koalisi partai politik pasca pelaksanaan pemilihan presiden.

Selain itu, adanya kenaikan harga BBM bersubsidi seiring dengan ekspektasi inflasi yang tinggi. Pada tahun 2015, terjadi pergerakan volatilitas nilai tukar yang meningkat. Di tahun tersebut, rupiah mengalami tekanan yang cukup tajam. Penyebab utama berasal dari eksternal Indonesia, yaitu masih berlanjutnya normalisasi kebijakan moneter Amerika Serikat, krisis utang Yunani, devaluasi yuan, serta divergensi kebijakan moneter global (Bank Indonesia, 2015). Sedangkan kondisi internal Indonesia mengalami perlambatan pertumbuhan ekonomi yang juga merupakan dampak dari perlambatan ekonomi global.

\section{Analisis Pengaruh Volatilitas Nilai} Tukar terhadap Kinerja Ekspor Utama Pertanian Indonesia

Setelah uji Hausman pada model regresi data panel pada gravity model ekspor karet alam, kopi, udang dan CPO Indonesia, diperoleh pendekatan Random Effect Model (REM) sebagai pendekatan terbaik untuk keempat komoditas ekspor tersebut.

Tabel 6. Hasil Estimasi Data Panel Ekspor Utama Pertanian Indonesia dengan Pendekatan REM

\begin{tabular}{ccccc}
\hline \multirow{2}{*}{ Variabel } & \multicolumn{3}{c}{ Komoditas Ekspor Utama Pertanian Indonesia } \\
\cline { 2 - 5 } & Karet Alam & Kopi & Udang & CPO \\
\hline C & -25.891 & -7.814 & 3.181 & -25.718 \\
\multirow{2}{*}{ VNT } & $(-6.907)$ & $(-4.110)$ & $(0.529)$ & $(-3.944)$ \\
& $-2.121^{* * *}$ & $-0.878^{* * *}$ & $-1.517^{*}$ & 0.585 \\
InGDPINA & $(-1.882)$ & $(-1.657)$ & $(-2.988)$ & $(0.754)$ \\
& $1.977^{*}$ & $0.482^{*}$ & $-0.477^{*}$ & $2.124^{*}$ \\
InGDPM & $(13.829)$ & $(4.059)$ & $(-4.939)$ & $(12.287)$ \\
InEDIST & $0.548^{*}$ & $0.683^{*}$ & 0.406 & 0.687 \\
& $(2.367)$ & $(8.666)$ & $(0.651)$ & $(0.832)$ \\
& -0.224 & $-0.511^{*}$ & -0.185 & -0.801 \\
\end{tabular}

Keterangan: t-stat berada dalam kurung ()

Signifikan pada taraf nyata $\left.\left.\left.{ }^{*}\right) 1 \%{ }^{* *}\right) 5 \%{ }^{* * *}\right) 10 \%$ 
Hasil estimasi data panel pada tabel 6 menunjukkan variabel volatilitas nilai tukar memiliki pengaruh negatif terhadap ekspor karet alam, kopi, dan udang Indonesia dengan koefisien masing-masing sebesar 2,$12 ; 0,87$; dan 1,51. Hal ini bermakna bahwa peningkatan 1 nilai standar deviasi volatilitas nilai tukar akan mengurangi ekspor karet alam, kopi, dan udang Indonesia masing-masing sebesar 2,12; 0,87 ; dan 1,51 , ceteris paribus. Variabel volatilitas nilai tukar yang bertanda negatif mengandung arti adanya pelaku usaha menghindari risiko sebagai akibat adanya ketidakpastian nilai tukar (Wang \& Barret 2007; Cho et al. 2002; Kandilov, 2008; Kafle \& Kennedy, 2011). Nilai tukar sangat erat kaitannya dengan harga komoditas ekspor dan kemudian berpengaruh terhadap keuntungan yang diterima. Adanya ketidakpastian harga yang disebabkan oleh ketidak pastian nilai tukar, petani sebagai pelaku usaha cenderung untuk menghindari risiko terutama bagi petani yang memiliki skala usaha kecil dan modal yang kecil. Sebesar $85 \%$ luas lahan karet dan 96\% luas lahan kopi Indonesia didominasi oleh perkebunan rakyat, sisanya dimiliki oleh swasta dan pemerintah (Ditjen Perkebunan, 2016a dan 2016b). Pada umumnya petani perkebunan rakyat masih dihadapkan oleh keterbatasan modal dalam usaha budidaya dan pemeliharaan. Munculnya ketidakpastian harga yang diakibatkan ketidakpastian nilai tukar, petani cenderung menerapkan berbagai langkah dalam menghindari kemungkinan kerugian yang terjadi. Langkah-langkah tersebut dapat menyebabkan turunnya tingkat produksi dan berimplikasi terhadap volume ekspor (Orden, 2002). Sebagai contoh, ketidakstabilan harga pada komoditas karet menyebabkan terjadinya konversi lahan dari tanaman karet ke kelapa sawit atau tanaman lain yang menguntungkan, bahkan kawasan industri dan pemukiman, serta kecenderungan petani karet untuk tidak melakukan penyadapan (Saputra, 2013; Syarifa et al. 2016). Wang dan Barret (2007) juga menjelaskan dalam penelitiannya bahwa rentannya ekspor pertanian terhadap volatilitas nilai tukar disebabkan oleh skala usaha tani yang kecil dan modal yang kecil.

Sama halnya dengan komoditas karet alam dan kopi, komoditas udang juga didominasi oleh peternak rakyat. Usaha budidaya udang hingga saat ini masih dilakukan oleh rumah tangga dan 
mayoritas dikelola secara tradisional dengan produktivitas rendah (Juarno, 2012; KKP, 2015). Selain hal itu, rentannya suatu komoditas terhadap volatilitas nilai tukar juga disebabkan oleh penggunaan input produksi yang berasal dari impor (Wang dan Barret, 2007). Pakan udang Indonesia hingga saat ini masih bersumber dari bahan baku pakan impor. Adanya ketidakpastian nilai tukar akan memengaruhi harga pakan udang, tentunya akan berimplikasi terhadap produksi udang. Hal ini sebagaimana penelitian yang dilakukan oleh Juarno (2012) bahwa harga pakan dapat memengaruhi produksi udang dan berdampak terhadap penawaran dan daya saing udang.

Variabel volatilitas nilai tukar terhadap ekspor CPO Indonesia memiliki koefisien sebesar 0.58 , namun tidak signifikan secara statistik. Berbeda dengan ekspor karet alam, kopi dan udang Indonesia, CPO Indonesia merupakan komoditas yang menggunakan lindung nilai (hedging) untuk menghindari risiko terhadap fluktuasi harga yang disebabkan oleh ketidakpastian nilai tukar dan harga CPO itu sendiri (Prihatini, 2015). Lindung nilai (hedging) komoditas CPO
Indonesia terdaftar di Bursa Komoditi dan Derivatif Indonesia (BKDI) dengan kode CPOTR. Lindung nilai (hedging) dilakukan dengan membeli atau menjual kontrak berjangka. Kontrak berjangka CPO merupakan salah satu kontrak berjangka yang diunggulkan di BKDI. Selain itu, CPO BKDI telah dijadikan salah satu acuan untuk penetapan Harga Patokan Ekspor (HPE) CPO (Prihatini, 2015).

Produk Domestik Bruto (PDB) riil Indonesia menunjukkan pengaruh yang positif terhadap ekspor karet alam, kopi, dan CPO Indonesia (Tabel 6). Hal ini dapat diartikan bahwa setiap kenaikan PDB riil Indonesia sebesar 1\%, maka ekspor karet alam, kopi, dan CPO Indonesia ke negara-negara mitra dagang utamanya akan meningkat masing-masing sebesar 1,$97 ; 0,48$, dan $2,12 \%$, cateris paribus. Sedangkan PDB riil Indonesia terhadap komoditas ekspor udang Indonesia menunjukkan pengaruh negatif dan signifikan dengan koefisien sebesar 0,47. Hal ini menunjukkan bahwa ketika terjadi peningkatan PDB riil Indonesia sebesar $1 \%$, maka akan menurunkan ekspor udang Indonesia ke negara-negara mitra dagang utamanya sebesar 0,47\%. Pada ekspor udang, meningkatnya 
PDB riil Indonesia akan meningkatkan pendapatan masyarakat, sehingga berdampak pada meningkatnya daya beli masyarakat terhadap udang Indonesia. Udang Indonesia yang diekspor merupakan udang kualitas terbaik, dengan meningkatnya pendapatan maka akan terjadi peralihan konsumsi ke produk dengan kualitas ekspor. Hasil penelitian ini senada dengan penelitian yang dilakukan oleh Ashari (2016) yang menyatakan bahwa kenaikan PDB akan menurunkan daya saing ekspor udang dan meningkatkan daya beli masyarakat terhadap udang kualitas terbaik (ekspor).

PDB riil negara-negara mitra dagang utama ekspor karet alam dan kopi Indonesia berpengaruh positif dan signifikan pada taraf nyata $1 \%$ dengan nilai koefisien masing-masing sebesar
0,54 dan 0,68 . Hal ini dapat dimaknai bahwa setiap kenaikan PDB riil negara mitra dagang utama sebesar $1 \%$, maka akan meningkatkan ekspor karet alam dan kopi Indonesia masing-masing sebesar $0,54 \%$ dan $0,68 \%$, ceteris paribus. Meningkatnya PDB negara mitra dagang akan mendorong permintaan ekspor. Hal ini disebabkan oleh adanya peningkatan volume produksi industri dan peningkatan daya beli masyarakat negara tersebut (Siliverstovs \& Schumacher, 2007; Kien, 2009). Hasil penelitian ini selaras dengan penelitian yang dilakukan oleh Rohmawati (2017) yang menyatakan bahwa PDB riil negara-negara mitra dagang utama berpengaruh positif dan signifikan terhadap ekspor karet alam Indonesia, dan penelitian Farida (2015) yang menyatakan hal serupa untuk ekspor komoditas kopi Indonesia. 


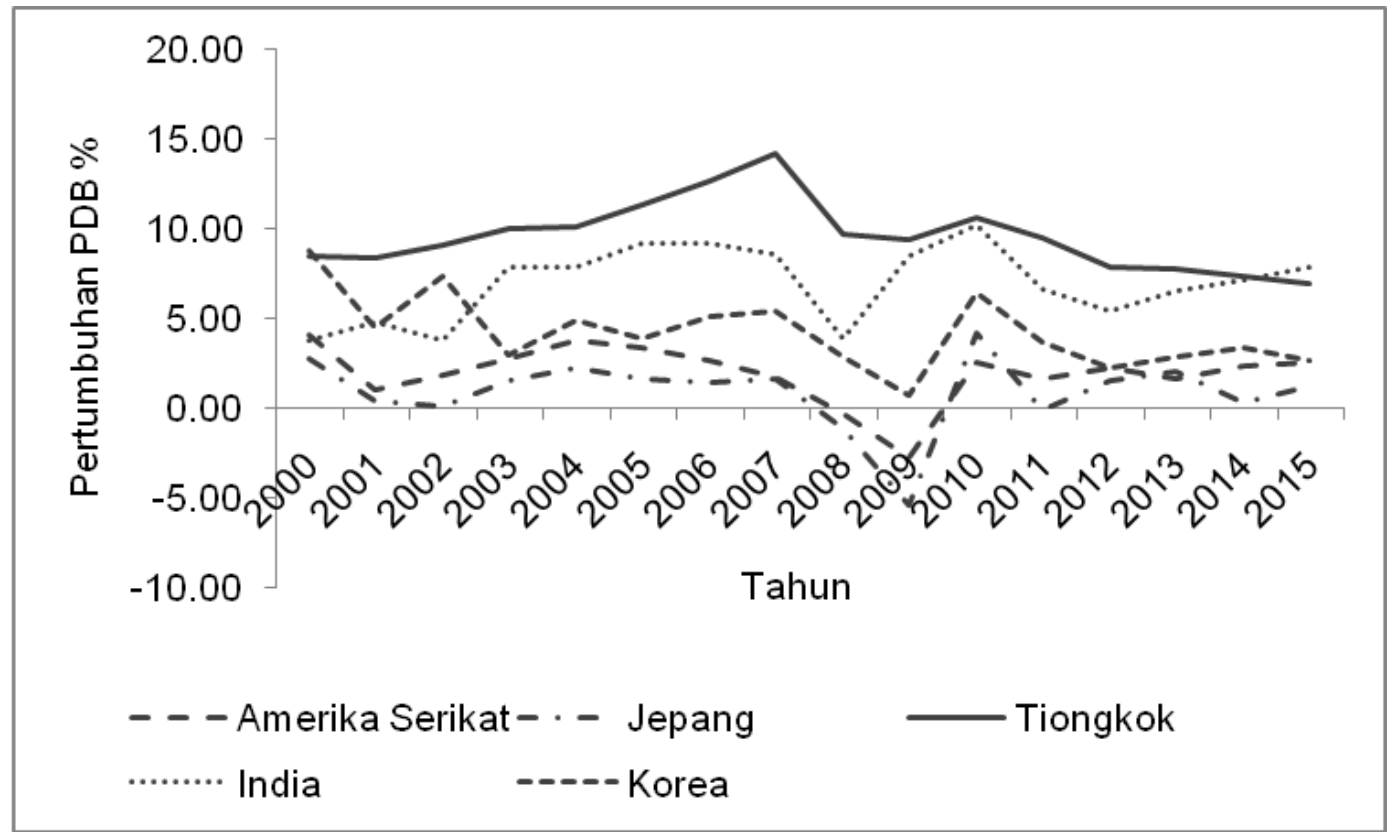

(a) Negara Mitra Dagang Utama Ekspor Karet Alam

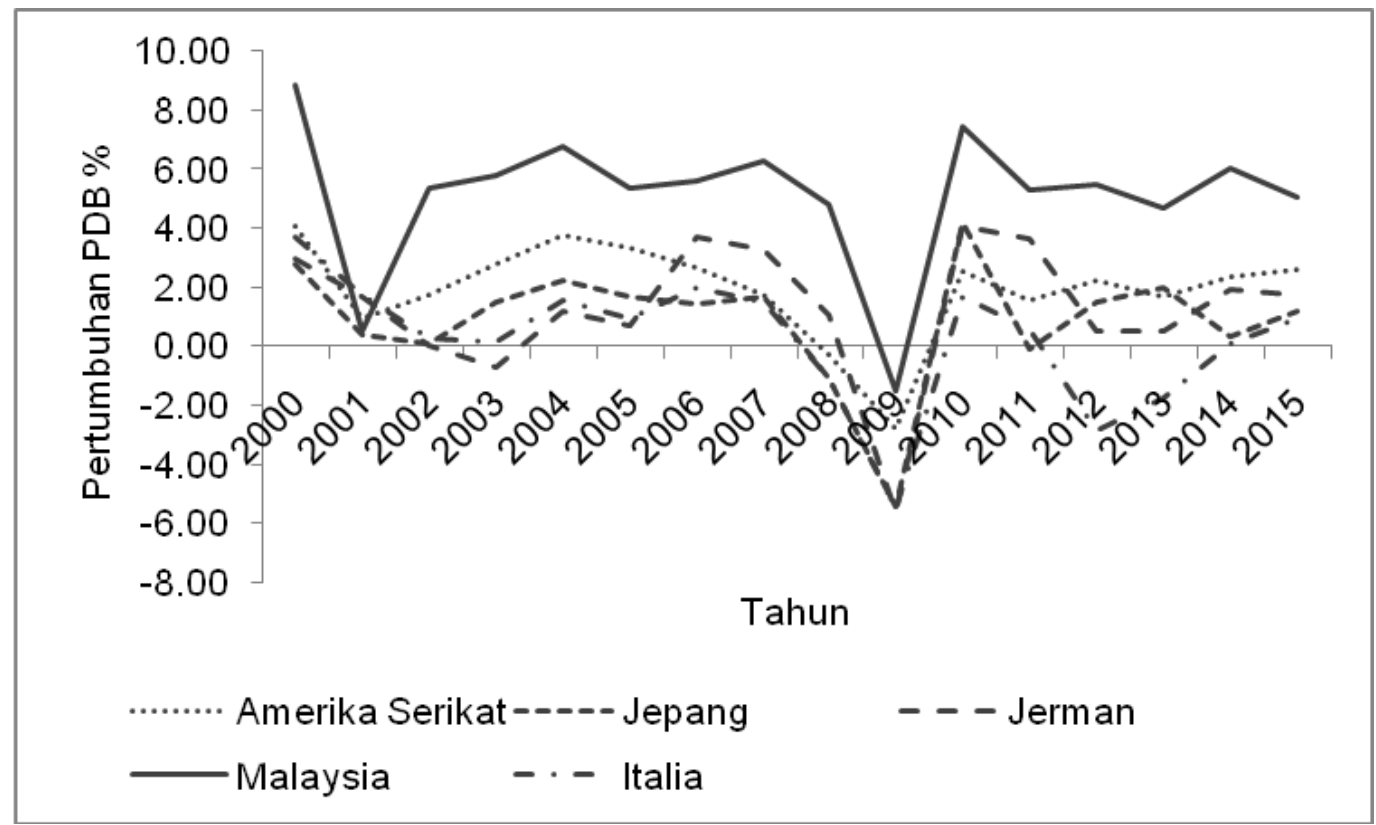

(b) Negara Mitra Dagang Ekspor Kopi

\section{Gambar 3 (a) \& (b). Pertumbuhan PDB Negara Mitra Dagang Utama Ekspor Karet Alam dan Kopi Indonesia}

Sumber: World Bank (2018)

Rata-rata pertumbuhan PDB diselang tahun 2000 hingga 2015 negara mitra dagang utama ekspor karet alam dan kopi Indonesia (Gambar 3). Di tahun 2008 dan 2009, menunjukkan pertumbuhan yang positif semua negara mitra dagang utama ekspor karet alam dan kopi Indonesia 
mengalami penurunan pertumbuhan dan beberapa negara pada tahun tersebut mengalami pertumbuhan yang negatif. Pada negara mitra dagang utama ekspor karet alam Indonesia, Amerika serikat dan Jepang menunjukkan rata-rata pertumbuhan PDB yang rendah dibandingkan negara mitra dagang lainnya, yakni dengan rata-rata pertumbuhan masing-masing sebesar 1,95 dan $0,90 \%$ per tahun. Tujuan ekspor karet alam Indonesia didominasi oleh kedua negara tersebut, dengan share sebesar 23,65\% ke Amerika Serikat dan $16,15 \%$ ke Jepang. Sehingga jika terjadi perubahan PDB Amerika Serikat dan Jepang, maka dapat memberikan pengaruh yang cukup berarti bagi ekspor karet alam Indonesia. Tiongkok dan India merupakan negara mitra dagang utama ekspor karet alam Indonesia yang memiliki rata-rata pertumbuhan PDB tertinggi (Gambar 3a). Rata-rata pertumbuhan PDB Tiongkok sebesar $9,59 \%$ per tahun dan India sebesar $6,99 \%$ per tahun. Pertumbuhan PDB yang tinggi tersebut memberikan efek kepada ekspor karet alam Indonesia. Permintaan karet alam Indonesia pada kedua negara ini relatif meningkat setiap tahunnya, dengan rata-rata pertumbuhan ekspor 1,78\% per tahun ke Tiongkok dan 19,01\% per tahun ke India. Sedangkan pada ekspor kopi Indonesia, rata-rata pertumbuhan PDB negara mitra dagang utama dibawah 5\% (Gambar 3b) yakni rata-rata pertumbuhan Amerika Serikat (1,95\%), Jepang $(0,90 \%)$, Jerman $(1,29 \%)$, dan Italia $(0,26 \%)$.

Pengaruh variabel jarak ekonomi terhadap ekspor kopi Indonesia menunjukkan pengaruh negatif dan signifikan dengan koefisien sebesar 0,57 . Hal ini dapat diartikan bahwa setiap kenaikan nilai jarak ekonomi sebesar $1 \%$, maka akan menurunkan ekspor kopi Indonesia sebesar 0,57\%, ceteris paribus.

\section{KESIMPULAN DAN REKOMENDASI KEBIJAKAN}

Hasil penelitian ini menunjukkan bahwa volatilitas nilai tukar berpengaruh negatif dan signifikan terhadap ekspor karet alam, kopi dan udang Indonesia, serta berpengaruh positif dan tidak signifikan terhadap ekspor CPO Indonesia. Pengaruh negatif menunjukkan adanya penghindaran risiko yang dilakukan oleh pelaku usaha disebabkan ketidak pastian nilai tukar. Pada akhirnya hal 
tersebut berimplikasi terhadap penurunan ekspor. Penelitian ini juga menunjukkan bahwa PDB Indonesia memengaruhi kinerja ekspor karet alam, kopi, dan CPO Indonesia secara positif dan signifikan (jika PDB Indonesia meningkat, maka akan meningkatkan ekspor tersebut). Sedangkan terhadap ekspor udang Indonesia berpengaruh negatif dan signifikan. Artinya, kenaikan PDB Indonesia akan menurunkan daya saing ekspor udang dan meningkatkan daya beli masyarakat terhadap udang Indonesia.

Pada PDB negara mitra dagang utama ekspor karet alam dan kopi memengaruhi kinerja ekspor kedua komoditas tersebut secara positif dan signifikan. Hal ini dapat diartikan bahwa peningkatan PDB negara mitra dagang utama akan meningkatkan ekspor karet alam dan kopi Indonesia. Namun, kondisi rata-rata pertumbuhan PDB negara mitra dagang utama ekspor karet alam dan kopi Indonesia menunjukkan pertumbuhan yang rendah.

Berdasarkan hasil penelitian tersebut, maka rekomendasi kebijakan yang diberikan yaitu (1) Adanya kecenderungan penghindaran risiko terhadap volatilitas nilai tukar yang berimplikasi terhadap penurunan ekspor, maka yang dapat dilakukan yaitu menjaga stabilitas nilai tukar, kemudahan akses ke lembaga keuangan, penerapan lindung nilai (hedging), dan kontrak jangka panjang (longterm contracts) serta menjaga pertumbuhan produksi komoditas. (2)

Dalam rangka mengurangi penurunan volume dan nilai ekspor keempat komoditas yang dianalisis, disarankan memperluas pasar ekspor dengan cara mencari pasar-pasar baru dengan tetap mempertahankan ekspor pada pasar yang telah ada.

\section{UCAPAN TERIMA KASIH}

Penulis mengucapkan terima kasih kepada Bapak Prof. Dr. Ir. Bonar Marulitua Sinaga, MA dan Bapak Dr. Faroby Falatehan, SP, ME yang telah memberi masukan dalam penulisan kajian ini, serta Adistiar Prayoga SEI, MM atas bantuan dan dukungan semangat kepada penulis.

\section{DAFTAR PUSTAKA}

Aftab, M., KBS. Syed, dan NA. Katper. (2017). Exchange-Rate Volatility and Malaysian-Thai Bilateral Industry Trade Flows. Journal of Economic Studies, Vol. 44(1), pp. 99-114.

Almawarni, A., C. Jolly, dan H. Thompson. (2007). Exchange Rates and Commodity Markets: Global Exports of Corn, Poultry, and Soybeans. 
Agricultural Economics Review, Vol. 8 (1), pp. 77-86.

Ashari, U. (2016). Integrasi Pasar dan Daya Saing Udang Indonesia di Pasar Internasional. Tesis. Bogor: Program Pascasarjana Institut Pertanian Bogor.

Asteriou, D., K. Masatci, dan K. Pilbeam. (2016). Exchange Rate Volatility and International Trade: International Evidence from the MINT Countries. Economic Modelling, Vol. 58, pp. 133-140.

Badan Pusat Statistik. (2008). Statistik Indonesia 2008. Jakarta: Badan Pusat Statistik.

Bank Indonesia. (2001). Laporan Perekonomian Indonesia 2001. Jakarta: Bank Indonesia.

Bank Indonesia. (2008). Laporan Perekonomian Indonesia 2008. Jakarta: Bank Indonesia.

Bank Indonesia. (2014). Laporan Perekonomian Indonesia 2014. Jakarta: Bank Indonesia.

Bank Indonesia. (2015). Laporan Perekonomian Indonesia 2015. Jakarta: Bank Indonesia.

Bank Indonesia. (2017). Kurs Referensi JISDOR. Diakses pada tanggal 6 Maret 2017 dari www.bi.go.id

Bollerslev, T. (1986). Generalized Autoregressive Conditional Heteroscedasticity. Journal of Econometrics, Vol. 31, pp. 307-327.

Broll, U, dan B. Eckwert. (1999). Exchange Rate Volatility and Trade. Southern Economic Journal, Vol. 66 (1), pp. 178-185.

Chit, MM., M. Rizov, dan D. Willenbrocked. (2010). Exchange Rate Volatility and Exports: New Emperical Evidence from The Emerging East Asian Economies. The World Economy, Vol. 33 (2), pp. 239-263.

Cho, G., I. Sheldon, dan S. Mc Corriston. (2002). Exchange Rate Uncertainty and Agricultural Trade. American Journal of Agricultural Economics, Vol. 84 (4), pp. 931-942.

Dell'Ariccia, G. (1999). Exchange Rate Fluctuations and Trade Flows: Evidence from The European Union. IMF Staff Papers, Vol. 46 (3), pp. 315-334.

Direktoral Jenderal Perkebunan. (2016a). Statistik Perkebunan Indonesia 20142016: Karet. Jakarta: Direktoral Jenderal Perkebunan.

Direktoral Jenderal Perkebunan. (2016b). Statistik Perkebunan Indonesia 20142016: Kopi. Jakarta: Direktoral Jenderal Perkebunan.

Direktoral Jenderal Perkebunan. (2016c). Statistik Perkebunan Indonesia 20142016: Kelapa Sawit. Jakarta: Direktoral Jenderal Perkebunan.

Engle, RF. (1982). Autoregressive Conditional Heteroscedasticity with Estimates of The Variance of United Kingdom Inflation. Econometrica, Vol. 50 (4), pp. 987-1007.

Farida, YSH. (2015). The Impact of NonTarif Measures on Indonesian Coffee exports: Evidence from the SPS and TBT Measures. Tesis. Bogor: Program Pascasarjana Institut Pertanian Bogor.

Firmansyah, M. (2016). Analisis Daya Saing Ekspor Kopi Indonesia di Pasar Internasional. Skripsi. Bogor: Fakultas Ekonomi dan Manajemen, Institut Pertanian Bogor.

Food and Agriculture Organization. (2002). The State of Food and Agriculture 2002. Roma: Food and Agriculture Organization.

Food and Agriculture Organization. (2008). The State of Food and Agriculture 2008. Roma: Food and Agriculture Organization.

Hardjanto, A. (2014). Volatilitas Harga Pangan dan Pengaruhnya terhadap Indikator Makro Ekonomi Indonesia. 
Tesis. Bogor: Program Pascasarjana Institut Pertanian Bogor.

Juarno, O. (2012). Daya Saing dan Strategi Peningkatan Ekspor Udang Indonesia di Pasar Internasional. Disertasi. Bogor: Program Pascasarjana Institut Pertanian Bogor.

Kafle, KR, dan PL. Kennedy. (2011). Exchange Rate Volatility and Bilateral Agricultural Trade Flows: The Case of The United States and OECD Countries. Journal of International Agricultural Trade and Development, Vol. 9 (2), pp. 211231.

Kandilov, IT. (2008). The Effects of Exchange Rate Volatility on Agricultural Trade. American Journal of Agricultural Economics, Vol. 90 (2), pp. 1028-1043.

Kementerian Perdagangan Republik Indonesia. (2017). Sepuluh Komoditi Utama dan Potensial. Diakses tanggal 17 Desember 2017 dari http://www.kemendag.go.id/id/econo mic-profile/10-main-and-potentialcommodities.

Kementrian Kelautan dan Perikanan. (2015). Kelautan dan Perikanan dalam Angka Tahun 2015. Jakarta: Kementrian Kelautan dan Perikanan.

Kementrian Kelautan dan Perikanan. (2013). Kelautan dan Perikanan dalam Angka Tahun 2013. Jakarta: Kementrian Kelautan dan Perikanan.

Kien, NT. (2009). Gravity Model by Panel Data Approach: An Empirical Aplication with Implications for The ASEAN Free Trade Area. ASEAN Economic Bulletin, Vol. 26 (3), pp. 77-266.

Klein, MW. (1990). Sectoral Effects of Exchange Rate Volatility on United States Exports. Journal of International Money and Finance, Vol 9 (3), pp. 299-308.

Langley, SV., M. Gugale., WH. Meyers, dan C. Hallahan. (2000).
International Financial Volatility and Agricultural Commodity Trade: A Primer. American Journal of Agricultural Economics, Vol. 82, pp. 695-700.

Mukhtar, T, dan SJ. Malik. (2010). Exchange Rate Volatility and Export Growth: Evidence from Selected South Asian Countries. SPOUDAIJournal of Economics and Business, Vol. 60 (3-4), pp. 58-68.

Muzendi, ASM. (2014). Integrasi Pasar dan Dampak Kebijakan Nontarif terhadap Permintaan Ekspor dan Daya Saing Kopi Indonesia di Pasar Internasional. Tesis. Bogor: Program Pascasarjana Institut Pertanian Bogor.

Orden, D. (2002). Exchange Rate Effects on Agricultural Trade. Journal of Agricultural and Applied Economics, Vol. 34 (2), pp. 303-312.

Ozturk, I. (2006). Exchange Rate Volatility and Trade: A Literature Survey. International Journal of Applied Econometrics and Quantitative Studies, Vol. 3 (1), pp. 85-102.

Pick, D. (1990). Exchange Rate Risk and US Agricultural Trade Flows. American Journal of Agricultural Economics, Vol. 72 (3), pp. 694-700.

Prihatini, AB. (2015). Analisis volatilitas dan hubungan harga spot-futures dengan ekspor Crude Palm Oil (CPO) Indonesia. Tesis. Bogor: Program Pascasarjana Institut Pertanian Bogor.

Rohmawati, S. (2017). Faktor-Faktor yang Memengaruhi Penawaran Ekspor Karet Alam dan Krustasea Indonesia ke Jepang. Skripsi. Bogor: Fakultas Ekonomi dan Manajemen, Institut Pertanian Bogor.

Rose, AK. (2000). One Money, One Market: The Effect of Common Currencies on Trade. Economic Policy, Vol. 30, pp. 7-46.

Saputra, A. (2013). Analisis Finansial Konversi Tanaman Karet Menjadi 
Tanaman Kelapa Sawit dan Dampaknya terhadap Distribusi Pendapatan di Kabupaten Muaro Jambi. Tesis. Bogor: Program Pascasarjana Institut Pertanian Bogor.

Senadza, B, dan DD. Diaba. (2017). Effect of Exchange Rate Volatility on Trade: Evidence from Selected SubSaharan African Countries. Journal of African Trade, Vol. 4(1-2), pp. 2036.

Shabrina, WA. (2016). Estimasi Hambatan Nontarif dan Faktor-Faktor yang Memengaruhi ekspor Kopi Indonesia ke Negara Tujuan Utama. Skripsi. Bogor: Fakultas Ekonomi dan Manajemen, Institut Pertanian Bogor.

Sheldon, I., SK. Mishra., D. Pick, dan SR. Thompson. (2013). Exchange Rate Uncertainty and US Bilateral Fresh Fruit and Fresh Vegetable Trade: An Application of The Gravity Model. Applied Economics, Vol. 45 (15), pp. 2067-2082.

Siliverstovs, B, dan D. Schumacher. (2007). Using The Gravity Equation to Differentiate among Alternative Theorities of Trade: Another Look. Applied Economics Letters, Vol 14, pp. $1065-1073$.
Syafendi, MR. (2014). Analisis Posisi Karet Alam Indonesia di Pasar Karet Alam China. Tesis. Bogor: Program Pascasarjana Institut Pertanian Bogor.

Syarifa, LF., DS. Agustina., C. Nancy, dan M. Supriadi. (2016). Dampak Rendahnya Harga Karet terhadap Kondisi Sosial Ekonomi Petani Karet di Sumatera Selatan. Indonesian Journal of Natural Rubber Research, Vol. 34(1), pp. 119-126.

Tweeten, L. (1992). Agricultural Trade, Principal, and Policies. San Francisco: Westview Press.

Wang, K, dan C. Barret. (2007). Effect of Exchange Rate Volatility on Export Volumes. Journal of Agricultural and Resources Economics, Vol. 32 (2), pp. 225-255.

World Bank. (2018). World Bank Data. Diakses pada tanggal 18 Agustus 2018 dari www.data.worldbank.org.

Zainal, AA. (2008). Pengaruh Volatilitas Nilai Tukar terhadap Volume Ekspor Beberapa Kelompok Komoditi Perdagangan Indonesia. Jurnal Ekonomi dan Pembangunan Indonesia, Vol. 8(2), $\quad$ pp. 147-173. 